\title{
Smart Tourism Destinations: (Mis)Aligning Touristic Destinations and Smart City Initiatives
}

\author{
Mariana Brandão Cavalheiro ${ }^{1}$ \\ Luiz Antonio Joia ${ }^{2}$ \\ Gabriel Marcuzzo do Canto Cavalheiro ${ }^{1}$ \\ Verônica Feder Mayer ${ }^{1}$ \\ ${ }^{1}$ Universidade Federal Fluminense, Niterói, RJ, Brazil \\ ${ }^{2}$ Fundação Getulio Vargas, Rio de Janeiro, RJ, Brazil
}

Received 06 November 2019. This paper was with the authors for one revision. Accepted 04 April 2021.

First published online 28 April 2021.

Editor-in-chief: Carlo Gabriel Porto Bellini (D) (Universidade Federal da Paraíba, João Pessoa, PB, Brazil)

Associate editor: Adriana Fumi Chim-Miki (10) (Universidade Federal de Campina Grande, UAAC, Brazil), Marcelo de Souza Bispo (ID) (Universidade Federal da Paraiba, CCSA, Brazil)

Reviewers: Melise de Lima Pereira (1) (Universidade Federal do Paraná, Brazil) and one anonymous reviewer

Editorial assistants: Kler Godoy and Simone Rafael (ANPAD, Maringá, PR, Brazil) 


\section{ABSTRACT}

Several tourism destinations around the world have started to implement smart city projects with the aim of improving the standard of living of their citizens, as well as the sustainability of their urban and touristic areas, which motivated the emergence of the concept of smart tourism destination. However, the extant literature on this subject is still incipient. Thus, this article aims to investigate, via an exploratory case study, whether the implementation of a smart city initiative in a touristic destination has helped it be transformed into a smart tourism destination. For that, a smart tourism destination development model is presented and applied as the theoretical lens adopted in this research. The results showed a clear misalignment between the smart city initiative and the touristic destination analyzed, as despite the opportunities arising from the technological infrastructure provided by the smart city project, the touristic sector of the city under analysis was not able to take advantage of the opportunities enabled by the smart city project. Lastly, one concluded that political discontinuity, missing local government tourism strategy and governance, lack of engagement of the citizens, and disregard for the local context were the main reasons for that misalignment.

Keywords: tourism destination; smart city; smart tourism destination; information and communication technology; tourism

JEL Code: Z3

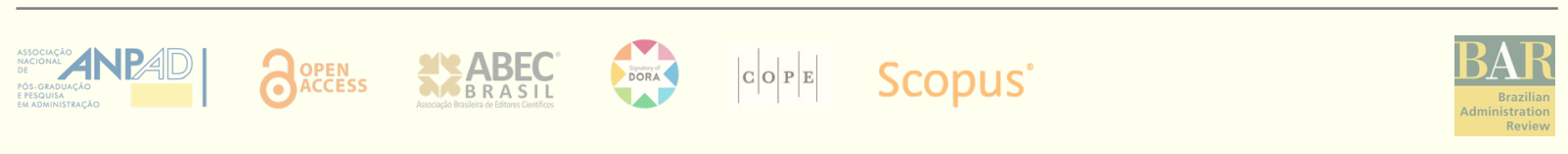




\section{INTRODUCTION}

Over the past six decades, travel and tourism (T\&T) has become one of the largest and fastestgrowing economic sectors in the world, currently accounting for $10.4 \%$ of global GDP and $6.5 \%$ of world exports (World Travel \& Tourism Council [WTTC], 2018). Accordingly, as argued by the World Tourism Organization, "every tourist means more jobs and business opportunities in tourism but also in related sectors" (World Tourism Organization [UNWTO], 2015, p. 1). As a consequence, the economic relevance of the $T \& T$ sector has been increasingly characterized by fierce competition between tourism destinations, involving touristic sustainability and improving positions in tourism rankings (Királ'ová, 2019; Koo, Shin, Gretzel, Hunter, \& Chung, 2016; Oye, Okafor, \& Kinjir, 2013).

Alongside the growing importance of the T\&T sector, another trend is the ever-increasing dependence of the society on information and communication technologies (ICT). For instance, in the T\&T arena, travel agencies are organizations increasingly dependent on ICT, as their operations require complex networks of collaboration among participants related to their value chains (Madalozzo \& Fernandes, 2016).

However, with the widespread adoption of ICT for personal and business use, the term 'smart' has become a new buzzword to describe all things that are embedded or enhanced by technology (Ramaprasad, Sánchez-Ortiz, \& Syn, 2017; Werthner, Koo, Gretzel, \& Lamsfus, 2015). According to Schaffers et al. (2011), when applied to cities the term 'smart' refers to an urban environment able to offer advanced and innovative services to citizens supported by pervasive ICT systems.

Smart city projects are becoming increasingly commonplace in the arena of $T \& T$, as various touristic destinations have started to implement their specific smart destination projects, which has led to the recent emergence of the concept of smart tourism destination (STD). In short, the concept of STD lays on specific cases of smart cities that have taken advantage of their technological infrastructures to promote an efficient and sustainable tourism development (Buhalis \& Amaranggana, 2013; Jasrotia \& Gangotia, 2018; Jovicic, 2019).

Despite the growing number of smart tourism destination projects, several scholars argue that 'smart,' especially in the case of tourism destinations, has become a very fuzzy concept often used to drive specific political agendas and to sell technological solutions (Gretzel, Sigala, Xiang, \& Koo, 2015; Michelotto, 2019). In fact, as far as STD is concerned, theory seems to have lagged behind the many government and industry-led projects (Gretzel et al., 2015; Jasrotia \& Gangotia, 2018), which reveals a real research gap. Due to that, the work of better conceptualize and define smart destination is underway, having gained considerable attention as a topic that urgently deserves both theoretical and empirical investigation (Werthner et al., 2015).

That way, this article addresses the abovementioned research gap by examining the specific topic of transforming a tourism destination into a smart one. Fundamentally, this study presents a case study of a smart city project implemented from 2011 to 2016 at the Municipality of Armação dos 
Búzios, Brazil ${ }^{1}$. More specifically, one applied the smart tourism destination development model (STDDM) proposed by Cavalheiro, Joia, and Cavalheiro (2020) as the theoretical lens to assess to which extent the implementation of a smart city initiative in Armação dos Búzios helped the city become a STD. In essence, the STDDM is a conceptual framework designed to describe the path a touristic destination must follow to become a smart one.

Therefore, the objective of this article is to provide a better understanding of the STD phenomenon, by examining the transformation process of an international touristic destination (Armação dos Búzios) into a smart city. In addition, by adopting a case study approach, one intends to analyze and discuss a real STD implementation process, focusing not only on the technological issues of the process but also including the contextual, structural, and political difficulties faced by tourism destinations, as suggested by Shafiee, Ghatari, Hasanzadeh, and Jahanyan (2019). Indeed, technology itself is not able to transform a destination into a STD tourism strategy and governance as well as human and political issues must also be taken into account (Ivars-Baidal, Celdrán-Bernabeu, Mazón, \& Perles-Ivars, 2019; Stephenson \& Dobson, 2020). Thus, by means of a case study, this research aims to reveal the potential obstacles to deploy a STD via smart city initiatives, thereby challenging the 'rose view' of some STD advocates.

In sum, this article purports to answer the following research question: How did the implementation of a smart city project in Armação dos Búzios impact the city to become a smart tourism destination?

\section{LITERATURE REVIEW}

\section{Smart city}

In the past few decades, the world has seen an increasing concentration of people in urban areas of both developed and developing countries (United Nations, 2015). Such rapid and unplanned urban growth has raised a variety of technical, social, and economic problems that have the potential to jeopardize the economic and environmental sustainability of cities (Global Agenda Council on the Future of Cities, 2015).

In the early 1990s, when the term 'smart city' was first used, one intended to highlight the importance of new ICT to overcome the challenges of cities within a global knowledge economy (Schaffers et al., 2011). More recently, the smart city concept was broadened, as scholars have acknowledged that factors such as human capital, education, and environmental issues are also drivers of a city's improvement (Ramaprasad et al., 2017).

In sum, smart city initiatives should start by assessing the characteristics of the respective city rather than blindly believing that ICT can automatically create a smart city (Zygiaris, 2013). Likewise, the implementation of a smart city initiative does not only mean to reach technological success but also to use technology to create public value, which can be classified into four types

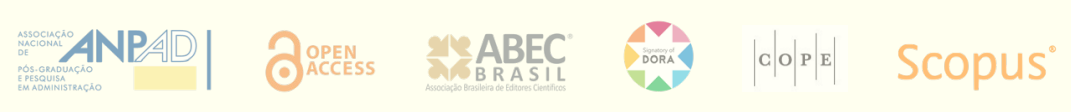


(Benington, 2011): (a) economic value; (b) social and cultural value; (c) political value; and (d) ecological value.

\section{Smart tourism destination (STD)}

With the growing recognition of the importance of tourism to an ever-increasing number of national and regional economies, achieving destination competitiveness is a central feature of the tourism policy debate (UNWTO, 2015). As such, while places and regions are being planned and transformed to attract more tourists and nonlocal investors (Buhalis \& Amaranggana, 2013), rivalry and competition between incumbent and promising touristic destinations increases (Oye, Okafor, \& Kinjir, 2013).

In general, STDs have been defined as special cases of smart cities that take advantage of the smart city technological infrastructure to enhance tourists' experience (Khan, Woo, Nam, \& Chathoth, 2017; Koo et al., 2016). Grounded on the concepts of sustainability, knowledge sharing, and technological innovation, a STD enables demands and supplies to co-create value for the tourist, as well as wealth, profit, and benefits for organizations and the destination itself (Munõz \& Sánchez, 2013). From the managerial and governance perspectives, STD infrastructure must be able to support close interaction and cooperation between the various stakeholders involved in the tourism industry (Buhalis \& Amaranggana, 2013). In this sense, MassukadoNakatani and Teixeira (2009) highlight the importance of the knowledge of local authorities about the resources available in their tourist destinations, in order to promote an effective management and governance of local tourism.

Regarding ICT, previous studies show that STD competitiveness is associated not only with hardware capabilities but also software ones, such as companies' and individuals' capabilities to use ICT (Ham, Koo, \& Chung, 2020; Jovicic, 2019). In this regard, Dursun and Caber (2016) described the possibilities of applying data mining techniques for identifying the profile of hotel customers who create the most value. Additionally, Madalozzo and Fernandes (2016) reported that travel agencies are increasingly dependent on ICT, as their operations require complex networks of collaboration between participants in their value chains.

In order to create a management model to STD, practitioners in Spain, driven by the State Secretary of Tourism, have published a standard (UNE 178501) that specifies the requirements for considering a tourism destination as smart. According to such standard, innovation, technology, universal accessibility, and sustainability are the four pillars that sustain smart tourism destinations (SEGITTUR, 2015).

On the other hand, academic theoretical studies have consistently addressed the challenge of building a STD framework. Buhalis and Amaranggana (2013) proposed a generic systematic framework to examine the role of ICT in successful tourism destinations. Shafiee et al. (2019), in turn, developed a conceptual model for promoting sustainability in smart tourism destinations. Moreover, Cavalheiro et al. (2020) have proposed the Smart Tourism Destination Development Model (STDDM), which can be characterized as a comprehensive framework to conceptualize 
different components of a STD and explain the strategic path to convert a tourism destination into a smart one. Due to its high comprehensiveness, the latter model is applied in this study, being explained in the section below.

\section{Smart tourism destination development model (STDDM)}

Based on the review, interpretation, and synthesis of a wide range of relevant literature on smart cities and tourism destinations, as well as aiming to fill a research gap, Cavalheiro et al. (2020) have proposed the STDDM, with the objective of improving the competitiveness of touristic destinations and creating public value (environmental, economic, socio-cultural, and political) from the STD for the local population and tourists as well.

There are few models linking smart city initiatives to STD endeavors. Most of the time, research on STD uses well-established models of acceptance of technology (such as TRA, TPB, TAM, TAM2, UTAUT, etc.) to explain the success/failure of these initiatives, which is a very reductionist and technocentric approach (Ye, Ye, \& Law, 2020).

Besides, there are other models that are extensions of extant frameworks on smart cities (Buhalis \& Amaranggana, 2013; Koo et al., 2016). In contrast, the STDDM herein adopted is a very comprehensive model developed specifically for smart tourism destinations, tackling the various aspects of a STD implementation and being also in line with the ideas of Shaffie et al. (2019) regarding the main dimensions and indicators to be taken into consideration when implementing and assessing a STD endeavor.

The STDDM comprises four layers as summarized on Table 1.

Table 1.

Layers of the smart tourism destination development model

\begin{tabular}{|c|c|c|}
\hline Layer & Title & Focus \\
\hline 0 & Tourism destination & $\begin{array}{l}\text { - Awareness/control of its own specific resources (endowed and/or } \\
\text { created) } \\
\text { - Enhancement of supporting factors and resources } \\
\text { - Concern for environmental sustainability } \\
\text { - Government support to the T\&T sector } \\
\text { - Tourism strategy definition (including local community) } \\
\text { - Integration, coordination, and cooperation among stakeholders }\end{array}$ \\
\hline 1 & Smart ICT infrastructure & $\begin{array}{l}\text { - Broadband network infrastructure } \\
\text { - Instrumentation } \\
\text { - Tourism integrated information platform }\end{array}$ \\
\hline 2 & Tourism applications & $\begin{array}{l}\text { - Smart-tailored services/applications } \\
\text { - Better STD management } \\
\text { - Opportunities for co-creation }\end{array}$ \\
\hline 3 & Smart destination & $\begin{array}{l}\text { - Desired by tourists } \\
\text { - Appealing to new investments and entrepreneur initiatives } \\
\text { - Promotes economic value, social and cultural value, political value, and } \\
\text { ecological value }\end{array}$ \\
\hline
\end{tabular}




\section{(a) Ground layer - the tourism destination}

In essence, the ground layer concerns the touristic destination readiness to become 'smart,' so it can consistently take advantage of a technological infrastructure (Cavalheiro, Joia, \& Cavalheiro, 2020). That is, a smart tourism destination project ought to first address the destination's resources, its capacity of delivering a competitive tourism product, and the needs, expectations, and perceptions of citizens and tourists. Accordingly, destinations should systematically analyze their resources to acknowledge their strengths and weaknesses/needs (Dwyer \& Kim, 2003).

In addition, a competitive tourist destination needs the commitment of the local government to support the tourism industry with efficient governance and marketing strategies (Oye et al., 2013). Likewise, the engagement of business, community leaders, and the community at large is essential to implement a stable identity and clear vision of the tourism destination (Dwyer \& Kim, 2003).

\section{(b) Layer one - smart ICT infrastructure}

The development of the T\&T sector is significantly associated with the ability to share information. On the one hand, the experiential tourism product cannot be evaluated before consumption (Xiang, Magnini, \& Fesenmaier, 2015). As such, travelers select one tourism destination over another based on information. On the other hand, destinations are complex coproducing networks that depend on the efficient sharing of information among the multiple 'producers' of tourists' experiences (Werthner et al., 2015). Therefore, according to Cavalheiro et al. (2020), the first task for developing a smart ICT infrastructure is to build a stable sturdy environment of broadband networks that enable the collection, communication, and integration of information coming from multiple sources. Consequently, the idea behind a smart ICT infrastructure is to create a tourism integrated information platform, scalable and cooperative, supporting the entire touristic experience in all its phases.

\section{(c) Layer two - tourism applications}

In essence, through layer one the destination is equipped with technological gear so as to become an ICT-integrated ecosystem (Cavalheiro et al., 2020). When the destination moves forward to layer two, this ICT-integrated ecosystem becomes a complex infrastructure of 'systems of systems.' The smart ICT infrastructure connects a range of technologies to support tourism, such as reservations systems, context-aware systems, autonomous agents searching and mining web sources, airline systems, security systems, transportation systems, as well as systems that create augmented realities (Koo et al., 2016).

\section{(d) Layer three - smart destination}

According to Cavalheiro et al. (2020), becoming a STD involves the smart use of ICT to create a sustainable and competitive tourism destination, which will ultimately promote public value creation within the host community. In fact, if a STD is developed according to the premises 
highlighted on the ground layer, the tourism activity might create four types of public value (economic value, social and cultural value, political value, and ecological value) as proposed by Benington (2011).

In sum, T\&T is a high-impact economic sector, a major job generator, and a priority area for an ever-increasing number of national and regional economies. As such, creating a STD is likely to promote economic value (Cavalheiro et al., 2020). Moreover, social and cultural value is created because building a STD passes by human capital investment aimed at fostering a destination's capacity for learning and innovating (Cavalheiro, 2017). Furthermore, as explained by Cavalheiro et al. (2020), when developed in a sustainable way, tourism can bring cultural pride and a sense of ownership and control, reducing vulnerability through diversification and development of skills and entrepreneurial capacity.

Likewise, in a STD, political value can be created since the planning stage, as it must count on the engagement of all stakeholders, such as citizens, companies, public authorities, not-for-profit organizations, etc. At last, since tourism destination's resources depend on the attractiveness of its natural and environmental conditions, tourism often provides the justification for environmental protection through, for example, the designation of national parks, therefore it fosters the creation of ecological value (Cavalheiro, 2017).

\section{RESEARCH METHOD}

This article adopted a case study research strategy, namely an empirical inquiry that investigates a contemporary phenomenon in real-life context, especially when the boundary between the phenomenon and the context is not evident (Yin, 2018). According to Stake (1988), case studies are of value in refining theory and suggesting complexities for further investigation, as well as helping establish the limit for generalizability.

Besides, the research was developed from a qualitative perspective. As suggested by Gephart (2004), the qualitative research can provide thick and detailed descriptions of actual actions in real-life contexts that recover and preserve the actual meanings that actors ascribe to these actions and settings. This methodological approach has proved to be useful and valuable in recent studies devoted to examining smart touristic destinations (Hristov \& Petrova, 2018; Racherla, Hu, \& Hyun, 2008).

In practice, one investigated and discussed the real impact of implementing a smart city initiative in Armação dos Búzios on the transformation of the city into a STD. For doing that, one used the smart tourism destination development model, proposed by Cavalheiro et al. (2020), as a guide to collect and analyze data.

As an exploratory case study methodological approach was used, this article did not test hypotheses formulated from the scientific literature. Smart tourism destination is a very recent knowledge field, thus, one conducted an exploratory single case study to assess, via the STDDM,

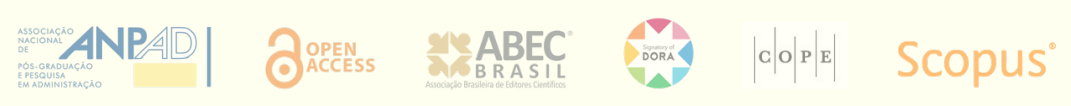


the results accrued from a smart city initiative named Cidade Inteligente Búzios ${ }^{2}$ (CIB). In other words, one analyzed and discussed the outcomes of the CIB project vis-à-vis the STDMM, in order to evaluate their potential to transform Búzios into a STD.

\section{Sample and data collection}

This article has its focus on a single case addressing the implementation of a smart city project in an international tourism destination. According to Yin (2008) and Mariotto, Zanni, and Moraes (2014), a single case design is appropriate when it represents a unique, revelatory, or critical case like the CIB project, since there are no other initiatives so far in Brazil of using smart city projects to transform a tourism destination into a smart one.

Moreover, multiple data collection techniques are typically employed in case studies. Ideally, evidence from two or more sources will converge to support the research findings (Yin, 2018). In this respect, data was collected through triangulation of several approaches, namely participant observation, semi-structured interviews, group discussions, and document analysis (project's reports, meeting records, field survey data, etc.).

In total, one conducted 23 semi-structured interviews for this research, before saturation via informant redundancy was attained. A list of the interviewees and their relation to the smart city project is summarized in Table 2. These interviews were staged between December 2015 and June 2017. They took on average 50 minutes and were all recorded and transcribed verbatim. The authors prepared the research instrument for the interviews as a roadmap to guide the process, containing the subjects that were supposed to be addressed by the respondents. These subjects are linked to the four stages - and their respective indicators - of the STDDM.

Moreover, meetings with a business class association $\left(\mathrm{AHB}^{3}\right)$ and an $\mathrm{NGO}\left(\mathrm{CIEDS}^{4}\right)$ were conducted in Armação dos Búzios by one author in May 2016 and April 2017, with the author taking advantage of staying in the city for an on-site inspection of the results of the smart city initiative.

During the last stay in the city, in April 2017, the author managed to have a copy of several reports and statistics related to the smart city initiative from the private company that sponsored the project, namely Ampla. 
Table 2.

Interviews

\begin{tabular}{cl}
\hline $\begin{array}{c}\text { Interviewees' } \\
\text { initials }\end{array}$ & \multicolumn{1}{c}{ Relation to the city/smart city project } \\
\hline WFC & Director of R\&D and innovation sector of Ampla \\
KR & Directors of Ampla's socioeconomic development and sustainability sector \\
BSL & CIEDS' person responsible for the CIB project \\
ML & Lives in Búzios - director of the local Hotels and Inns Association (AHB) \\
GAS & Lives in Búzios - temporally hired by Ampla to work at the projects monitoring and research center in Búzios \\
TTL & Lives in Búzios - temporally hired by Ampla to work at the projects monitoring and research center in Búzios \\
MLM & Employer at the Búzios' Secretariat of Tourism \\
ES & Director of Tecnoclad (proposes/develops R\&D projects for electricity distribution dealers) \\
MA & Researcher from COPPE/UFRJ - external institution that developed the distributed generation research for the \\
EM & project \\
PS & Ampla's R\&D and innovation sector staff \\
JR & Tourist \\
JRA & Lives in Búzios - taxi driver \\
AC & Lives in Búzios - secretary of science and technology \\
WS & Lives in Búzios - secretary of tourism \\
RS & Lives in Búzios - condo gatekeeper \\
FS & Lives in Búzios - inn owner \\
MMC & Lives in Búzios - inn owner \\
GCC & Has a house in Búzios - doesn't live in the city \\
VV & Tourist \\
BF & Lives in Búzios - hotel front desk \\
RV & Ampla's employee responsible for the project's automation network \\
WR & Ph.D. student at UFF - researcher in the project \\
\hline
\end{tabular}

\section{Data analysis}

In case studies, data from multiple sources should be converged in the analysis process, rather than handled individually (Stake, 1998). As such, the data analysis process consists of both triangulating data sources and developing a coding scheme, aiming at grouping similar events under a similar heading. Additionally, to analyze large amounts of qualitative data derived from documentary sources and interviews, this stage of the research was performed with the assistance of Atlas TI software.

In order to meet Yin's (2018) premises associated with the academic rigor of a case study, the following points were considered: construct validity, internal validity, external validity, and reliability.

To validate the construct, the tactic of multiple data sources (interviews, direct and participant observation, and consultation of records in files) was applied, in order to establish a chain of evidences related to the research question of the study. Specifically, the existing records related to the CIB project were collected to ascertain the frequency of use of the CIB project by the local population and tourists. 
For internal validation, no mechanism was used, as this is a concern only for explanatory case studies (Yin, 2018).

Besides, for external validation, the logic of analytical generalization (Yin, 2018) was applied, seeking to use a previously developed theory as a model with which to compare the empirical results obtained in the case. In fact, in this research it was more important to generalize the process of conducting the case than the observed results (Lukosevicius, Marchisotti, \& Soares, 2017), as the latter depend heavily on the local context (Avgerou, 2019; Davison \& Martinsons, 2016).

Finally, reliability was ensured through the creation of a repository of data and information, many of them contained in a virtual environment, as well as a protocol for preparing the case study, aiming that, if reproduced by another researcher, the study would lead to results similar to those herein obtained (Yin, 2018).

\section{“CIDADE INTELIGENTE BÚZIOS” PROJECT: DESCRIPTION AND EVALUATION}

As argued by Stake (1998), to study the case and probe its particularities, it is important to investigate the nature of the case, its historical background, and physical setting. Therefore, one started the research by exploring the setting wherein the case is embedded, as explained hereafter.

\section{Armação dos Búzios}

Lying in northern Rio de Janeiro state, the city of Armação dos Búzios, which is locally known as just Búzios, is situated in the micro-region of Lagos, about 173 kilometers distant from the state capital (Instituto Brasileiro de Geografia e Estatística [IBGE], 2016). The city comprises an area of $70,278 \mathrm{~km}^{2}$ and has been recognized as an emancipated city since 1995 . Over the last 40 years, the city has experienced a significant population growth - while in 1970 the number of Búzios' inhabitants was 4,108 (CEPERJ, 2001), nowadays one estimates that 31,674 people live in Búzios ${ }^{5}$ (IBGE, 2016).

Búzios is characterized as an urban city (IBGE, 2016) and the economy revolves around the oil royalties, real state, and mainly tourism, which is commonly appointed as the city's 'vocation.' As such, every year the city attracts a highly diverse audience of national and international tourists. In fact, in 2011 Búzios was ranked as the fifth tourism destination in Brazil regarding international tourists (Ministério do Turismo, 2012).

Nevertheless, such economic prosperity has not led to the wellbeing of the local community. As explained by Sales and Alves (2010), tourism has been changing the socio-spatial arrangement of Búzios over the last 30 years, thereby triggering issues such as real estate speculation, increased waste production, and deforestation in areas of environmental protection.

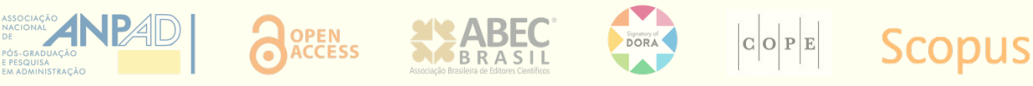




\section{Cidade Inteligente Búzios (CIB)}

In 2011, an electricity distribution dealer under the Enel Brasil holding, Ampla Energia e Serviços S.A, launched a project (Cidade Inteligente Búzios - CIB) aimed at transforming Búzios into the first smart city of Latin America (Vilaca et al., 2014). Accordingly, that company decided to make the town a smart city lab, similar to the ones that exist in Málaga (Spain) and Masdar (Abu Dhabi) (KPMG, 2012). Moreover, one of the main reasons for Búzios being chosen as the host of the smart city project was that, as a tourism destination, not only the local citizens but also travelers from all over the world would be benefited and learn about the project (Guimarães, 2015).

STDs are special cases of smart cities that take advantage of the existing technological infrastructure to promote efficient and sustainable development, to increase residents' quality of life and also to enhance tourists' experiences (Jasrotia \& Gangotia, 2018; Munõz \& Sánchez, 2013). Thus, it is possible to infer from Ampla's reports on this initiative that the CIB project intended to transform Búzios not only into a smart city but also into a smart tourism destination.

The CIB project was originally proposed as a response to federal regulatory requirements of the Brazilian electricity market. In fact, since 2000, electricity distribution dealers that operate in Brazil, such as Ampla, are required by law to invest annually at least $0.75 \%$ of their net operating revenue in $R \& D$ projects (Agência Nacional de Energia Elétrica [Aneel], 2012). These substantial financial resources can be spent on the company's own R\&D sector or to sponsor studies carried out by universities and research centers. In order to comply with this obligation, companies must submit their projects to the National Electricity Agency (Aneel).

In this context, in August 2011, Ampla submitted a project proposal named CIB - Cidade Inteligente Búzios - for Aneel initial evaluation. The pilot project had a wide scope with relevant investments and the participation of nearly 40 professionals. In October 2011, Aneel issued a favorable opinion and shortly after this Ampla started to implement the CIB project. The CIB project was carried out between November 2011 and October 2016, and its total cost exceeded US\$ 20 million. More than half of this amount was sponsored by the financial resources Ampla had to invest by law in R\&D.

\section{Applying the smart tourism destination development model}

In order to analyze the impact of the CIB smart city project on transforming Búzios into a smart tourism destination, the STDDM was applied. Thus, the implementation of the CIB project was investigated through the four layers proposed by Cavalheiro et al. (2020) associated with the triangulation of evidences obtained in the interviews, direct and participant observations, and analysis of records on file.

\section{(a) The tourism destination}

Essentially, a smart destination project must start by addressing the destination's resources and its ability to deliver a competitive tourism product. The concern with environmental

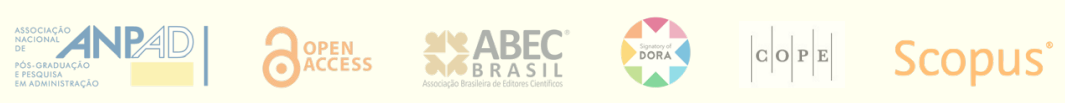


sustainability is another critical aspect for the development of a STD. In addition, the importance of local government commitment to support the T\&T sector (Cavalheiro et al., 2020) is highlighted. The observations and excerpts from the interviews related to these requirements are presented below.

'Awareness/control of its own specific resources' - In 2010, the Brazilian Ministry of Tourism, in partnership with Búzios' Secretariat of Tourism and Culture, hired a private institute to develop the city's tourism inventory. The final document was released in 2011 and, according to such inventory, Búzios had 106 cultural attractions, including 25 buildings and monuments, 11 cultural institutions or groups, and 50 events/happenings. Moreover, the region has 30 beaches, eight islands, 12 rivers, and 37 bays, mountains, and caves. Regarding the city's touristic infrastructure, 290 lodging facilities, 47 travel agencies, and 277 gastronomy establishments were registered. In addition, this tourism inventory catalogued 41 shopping spaces - fairs, galleries, shopping malls, and markets - 18 vacation rental companies, 12 transportation companies, 11 tourism guides, and 10 tourism associations.

However, according to the city's current secretary of tourism, such inventory was poorly developed, based mainly on secondary data - at best, it was incomplete. In Búzios, many tourism trade organizations are informal, and an in-depth field survey would be required to gather all necessary information about the city's tourism sector.

'Enhancement of supporting factors and resources' - As an electricity distribution dealer headed the smart city project, a significant enhancement was made in Búzios lightening supply, as observed by the director KR:

"When the city was crowded, we usually had power shutdown... However, in the last two big holidays, New Year's Eve and Carnival, we had no problem."

However, other city's basic infrastructure such as mobility, waste collection, and water distribution remained deficient. For instance, a tourist from Southern Brazil has told that on December 31, 2016, returning from the beach to the place he was staying (about three and a half miles distant) took him two hours, because of a massive traffic jam. Likewise, an inn owner has complained that because of the inefficient sewage system, sometimes the sewage sprouts near his hotel creating a terrible image for his guests.

According to Búzios secretary of tourism, the problem is that the public authorities fail to understand that Búzios is a tourism destination. Indeed, the number of people living in the city is about 30,000, but this is not the number of people in the city. In fact, no one knows the accurate number of people staying in the city. It is estimated that during high season, the number of tourists gets to 300,000 , but as told by the secretary of tourism, this number is less than an estimation, it is a bet.

'Concern for environmental sustainability' - One of the first actions of the smart city project was to implement an incentive program for waste recycling. In January 2012, Ampla has signed a partnership with the Municipal Secretariat of Environment and Fisheries and with the regional 
cooperative of collectors of recyclable materials (Cocare) to develop this program, which included the exchange of recyclable waste for bonuses in the electricity bill.

Furthermore, throughout the project implementation, Ampla's department of sustainability projects has been engaged in educating the local community about energy conscious consumption. Besides offering open lectures to the local community, they have sealed a partnership with Búzios Secretariat of Education to add to the municipal school's curriculum the subject of energy conscious consumption and issues related to sustainability. Regarding the technological aspect of the project, Ampla has supported several types of research intended to develop instruments to generate power from renewable sources of energy (solar and wind).

'Government support to the T\&T sector' - As abovementioned, Búzios became an emancipated city in 1995 and according to Frossard (2004) the first elected government had invested a great deal in organizing and ordering the tourism activity. Indeed, Búzios became one of the main touristic destinations in Brazil. However, because of the discontinuity of projects and actions on the tourism planning, as well as a lack of commitment of some public managers, the city has not been able to overcome typical problems of tourism destinations, compromising the quality of life of its citizens and the environmental sustainability.

As told by an employer of Búzios Secretariat of Tourism and Culture, the amount of information lost every time there is a change in the municipal government is 'unbelievable.' Much of the information concerning the city tourism activity is not organized and only printed papers are kept. When a new secretary assumes, all the paperwork from the previous administration end up going to a dead file and new actions need to be created from scratch.

Concerning the CIB project, it is important to bear in mind that it was conducted by a private company, which had its own interests and limited legal power. When the project was launched, Ampla managed to get the City Hall on board. The close relationship with the City Hall favored the project development at the beginning. However, Ampla was not able to predict that the then mayor would not be re-elected at the 2012's elections, compromising the City Hall engagement achieved so far. As explained by the director of $R \& D$ and innovation sector of Enel group in Brazil (WFC):

\footnotetext{
"The project began in the previous mayor government, and the mayor who won the 2012's elections was from the opposition party. So, to be honest, for him it would be good if the project failed. Unfortunately, this kind of discontinuity happens every time a political party loses the power to the opposition."
}

Thus, from the transcribed excerpts, a recurrent discontinuity in the support of the City Hall to tourism projects in Búzios is noticed whenever a change of government occurs and the political opposition takes power. It seems that touristic developments in Búzios belong more to the municipal power than to society, and are often used as marketing and advertising tools by the then City Hall, aiming to increase the national and international visibility of Búzios - which is not uncommon in the tourism sector (Coca-Stefaniak, 2019; Femenia-Serra \& Ivars-Baidal, 2021; Gretzel et al, 2015). Therefore, in 2013 the project not only lost the engagement of the City Hall but also had to face the new mayor's resistance.

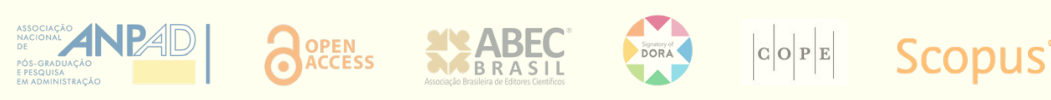


This can be verified in the transcript below of MMC (owner of a house in Búzios and a vacationer who lives in Rio de Janeiro):

"Municipal governments have used tourism projects as marketing and advertising tools. The main concern of any City Hall in Búzios has been to attract national and international tourists who will spend their money here. This increases the city's financial revenue but does not solve the various infrastructure problems the city has faced so far."

'Tourism strategy definition (including the local community)' - In order to engage the local community to the CIB, a social development block was created within the project. In addition, an NGO named CIEDS (Centro Integrado de Estudos e Programas de Desenvolvimento Sustentável) was hired to integrate the citizenry to the project in 2012.

In Búzios, CIEDS created what they call the sustainable network of relationship (SNR). This network would function as a channel of continuous communication and articulation around the issues concerning the development of Búzios as a smart city. Special attention was given for the enhancement of the city's social capital, sustainability, and innovation. Several local actors were involved in this network, such as associations, NGOs, and public authorities.

CIEDS' efforts in building the SNR resulted in the association of 40 institutions that represented about $33 \%$ of the city's inhabitants. Such network was divided into five technical chambers Qualification and Income Generation; Tourism and Economic Activities; Energy and Smart City; Public Services, Transparency, and Supervision; Social, Cultural, and Educational Projects - to discuss and propose actions for issues involving different subjects within the city.

Through SNR meetings, some targets for the development of the tourism sector in Búzios were set, namely protection of the city's natural resources, strength of local entrepreneurship, development of a sustainable city image, increase of local income generation, and creation of a sense of belonging among Búzios' citizens.

'Integration, coordination, and cooperation among stakeholders' - The integration, coordination, and cooperation among stakeholders were fostered by the Sustainable Network of Relationships, especially through the Tourism and Economic Activities technical chamber. However, after a few meetings and the depart of the government support, the integration among the tourism stakeholders lost its power.

In addition, the CIB project is a public-private partnership (PPP) between the Municipality of Búzios and Ampla. This type of collaboration has been very common in the field of tourism (Errichiello \& Marasco, 2017). However, it is clear that due to the political discontinuity that occurred in the municipal political power of Búzios, the PPP was closed before the full implementation of the CIB project, compromising the results obtained.

\section{(b) Smart ICT infrastructure}

According to Cavalheiro et al. (2020), the first task for developing a smart ICT infrastructure is 
to build a stable sturdy environment of broadband networks (in optical fiber) that enables the collection, communication, and integration of information coming from multiple sources.

To implement smart grid within the CIB project, which according to Ampla represents the technological ground for the development of smart cities, there was a specific block of actions called telecommunications and systems (Vilaca et al., 2014). This block was responsible for the integration of heterogeneous communication technologies such as power line communications (PLC), mesh network, fiber optics, and radio frequency (RF) for multiple simultaneous applications, creating an efficient and unified solution for a smart grid design. In addition, the network was developed with hybrid data transmission architecture. Thus, through the CIB project, telecommunication infrastructure in optical fiber (129 kilometers) was taken to Búzios.

Besides having a fiber optics network infrastructure, in a STD such network is supposed to be instrumented, namely supplied with embedded systems, smart devices, sensors, and actuators, offering real-time data. Regarding the CIB project, the network supported a public lighting system, distribution network automation, electronic metering, distributed generation system, and electric vehicles charging stations. Moreover, all the data collected is stored for analyses and research regarding the smart grid development.

Once again, it is worth to recall that a private company of the energy sector headed the CIB project. Thus, it is no surprise that all instrumentation of the network was related to energy. On the other hand, the developed network infrastructure may now be used by other sectors such as travel and tourism.

\section{(c) Tourism applications}

With the smart ICT infrastructure implemented, two tourism applications were developed within the CIB project. The first was an electronic bicycle rental service. To develop a state-of-the-art smart grid, Ampla sought to make the existing network able to support an electric vehicle supply system. In order to test this system, they needed to have electric vehicles running in the city. As such, Ampla acquired a fleet of three electric cars and 52 bicycles. The cars were used by the people working in the project. Thirty bicycles were loaned to a tourism company so they could be rented for sightseeing, while the others were donated to the City Hall to be used by the municipal guard. The bikes used by tourists were equipped with GPS so they could be traced.

From the point of view of the owner of the travel agency renting the bikes, at first, the bike rental seemed to be a good and viable touristic service. However, the electric bicycles bought by Ampla were developed to run in urban areas with paved roads in regular state of conservation, while Búzios' streets are paved with stones. Therefore, the bicycles often got broken, and the maintenance costs were very high. In the end, the tourism company returned the bicycles to Ampla and gave up of renting the electric bikes.

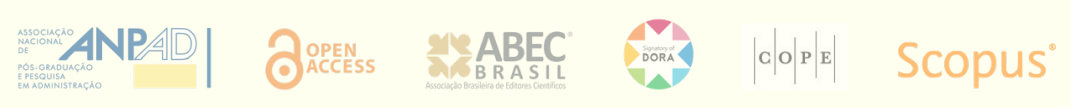


The other tourism application that emerged within the CIB project was a touristic information mobile app. The idea of this app came from the SNR meetings. As explained by the CIEDS person responsible for the CIB project (BSL):

\footnotetext{
"The idea was to develop a mobile application so that people visiting Búzios could access it... and that the organizations that are part of the network [SNR] could be found in it... In this way, people would know that Búzios' attractions go beyond the wonderful beaches."
}

Thus, with the aid of Ampla, the touristic information mobile app was developed, called Cidade Inteligente Búzios Guia. The app is free for download, being available for Android and IOS. It includes a map of Búzios with the city's touristic attractions, the spots where CIB research was developed, as well as tourism enterprises in Búzios (hotels, inns, restaurants, travel agencies, and other service providers). However, despite Ampla's efforts in developing the technological side of the app, few people from the SNR added information about the city to the app. Thus, the application lacks information and is therefore poorly evaluated by its few users, since a large part of the population was unaware of it, as can be seen below through the statement of a local citizen (WR):

"I haven't ever heard about any apps for tourists or local citizens. What are they about?"

\section{(d) Smart destination}

According to Cavalheiro et al. (2020), STDs are special cases of smart cities that take advantage of technological infrastructure to enhance tourists' experience and improve destination competitiveness. However, a STD should also be aimed at creating public value for the local people.

'Tourism destination competitiveness' - One observed that after the CIB project implementation, the tourists' experience did not improve to the point of exceeding the expectations they already had about the destination. In fact, if on the one hand they have not experienced power shutdowns as often as before, on the other hand several other city's basic infrastructures such as mobility, waste collection, and water distribution remain deficient.

Regarding Búzios competitiveness as a touristic destination, it has at best been maintained the same. Búzios continues to be the fifth destination in Brazil to receive more international tourists (Ministério do Turismo, 2017). However, according to the Brazilian Ministry of Tourism's competitiveness index of the national tourism destinations, from 2011 to 2015, Búzios dropped from the $49^{\text {th }}$ place to the $50^{\text {th }}$ (Barbosa, 2012; Ministério do Turismo, 2015). According to an inn owner, who lives in Búzios for more than 11 years, they are not only losing tourists for other destinations, mostly in the northeast of Brazil, but the 'quality' of Búzios tourists got worse. As RS put:

"They come in big groups and rent a tiny house... are rude, produce a lot of waste and do not spend much money in the city." 
In the end, despite being able to create some public value within the city, the CIB project was not enough to make Búzios a smart destination. As observed by a Búzios travel agency owner.

"It would be good to sell Búzios as a Smart City or Smart Destination, but Búzios is neither of it."

'Public value creation' - The CIB project had some positive impacts on the quality of life in Búzios that go beyond the improvement of lighting supply. As abovementioned, the CIB project, besides aiming at developing and implementing new technologies in Búzios, was also concerned with the social development of the city. After CIEDS' efforts in capacitating the SNR's members in project development and fund-raising, two new entrepreneur projects were implemented, with the potential of creating economic value within areas of social vulnerability, namely Marine Farm development and the Quilombola's black dolls manufacturing.

The Quilombola project is also an example of social and cultural value creation within the CIB project. Quilombolas are rural communities that group descendants of Afro-Brazilian slaves, living in a subsistence culture and where cultural manifestations have strong ties with the past. This project developed with the aid of the SNR, besides targeting income generation for a Quilombola community of Búzios, also intends to rescue the Afro-Brazilian culture. In fact, the doll manufacturing is just the first action of a project that seeks to create a new tourism product in Búzios.

On the other hand, it was observed that the political value of the project for the city was reduced. Despite Ampla and CIEDS' efforts in developing the SNR, the resistance of the City Hall starting at the 2012's elections - and the subsequent change in government harmed the possibility of creating political value. Moreover, the SNR has failed to become sustainable to maintain itself without the CIB project. Therefore, as soon as the project ended and CIEDS left Búzios, the SNR ended.

In addition, although Ampla and CIEDS believed that most of Búzios' population was being represented in the SNR, this was not true. Information about the project was not disclosed among the citizens, who in turn and by consequence did not follow up the project implementation. More than once, when asking Búzios' residents about the CIB project, they were unable to explain what it was about. For instance, a taxi driver who lives in Búzios answered the following:

"I don't know what it is or how it works."

At last, one also observed some creation of ecological value within the CIB project, with incentives being created for waste recycling as well as community lectures about energy efficiency and environmental protection. However, these actions are too small when compared to the potential possibilities of ecological value creation in a real STD. 


\section{DISCUSSION OF THE CASE}

The case under analysis provided an important opportunity to generate empirical evidence to assess, via the STDDM, smart tourism destinations initiatives. In order to illustrate this, Figure 1 was developed highlighting the major issues associated with the CIB project implementation.

Therefore, after examining the $\mathrm{CIB}$ project implementation, one triangulated the excerpts obtained from the interviewees, the observations got from the site, and the information about the CIB project vis-à-vis the STDDM.

It was possible to identify a set of steps a tourism destination must accomplish in order to become a smart one. First of all, a tourism destination must be ready to become smart. Fundamentally, technology will not act by itself in order to organize a tourism destination value chain and create public value (Cavalheiro et al., 2020). Such readiness encompasses the analysis of the tourism destination infrastructure, the development of a clear and achievable tourism strategy, and the commitment of government authorities, tourism trade companies, and the hosting community to this strategy (Koo et al., 2016; Oye et al., 2013).

In fact, the case analysis has shown that, despite being the less technological layer of the STDDM, the ground layer can be the most complex one. As observed, the analysis of the tourism infrastructure needs to go beyond the gathering of tourism companies, as many tourism service providers are informal. Besides, the commitment of government authorities can be quite unsteady, being susceptible to elections results and political power change as also argued by Gretzel, Sigala, Xiang, and Koo (2015) and Boes, Buhalis, and Inversini (2016). This can be a problem as most STD initiatives are based on public-private partnerships (Errichiello \& Marasco, 2017). Furthermore, engaging the local people in this kind of project might be difficult, especially when these people are not used to get involved in the city's business or to be heard, as is also supported by Cornejo-Ortega and Malcolm (2020).

Thus, without properly developing the ground layer, Búzios was not able to take advantage of the smart ICT technological infrastructure to become a STD and improve its tourism competitiveness. As perceived in the case description, the CIB project was built in a stable sturdy environment of broadband networks that enables the collection, communication, and integration of information coming from multiple sources. Additionally, such infrastructure has been in some way instrumented - supplied with embedded systems, smart devices, sensors, and actuators, offering real-time data. However, with the lack of ground to become a STD, the tourism stakeholders in Búzios seemed to be unaware of the possibilities that have come with such ICT infrastructure. 


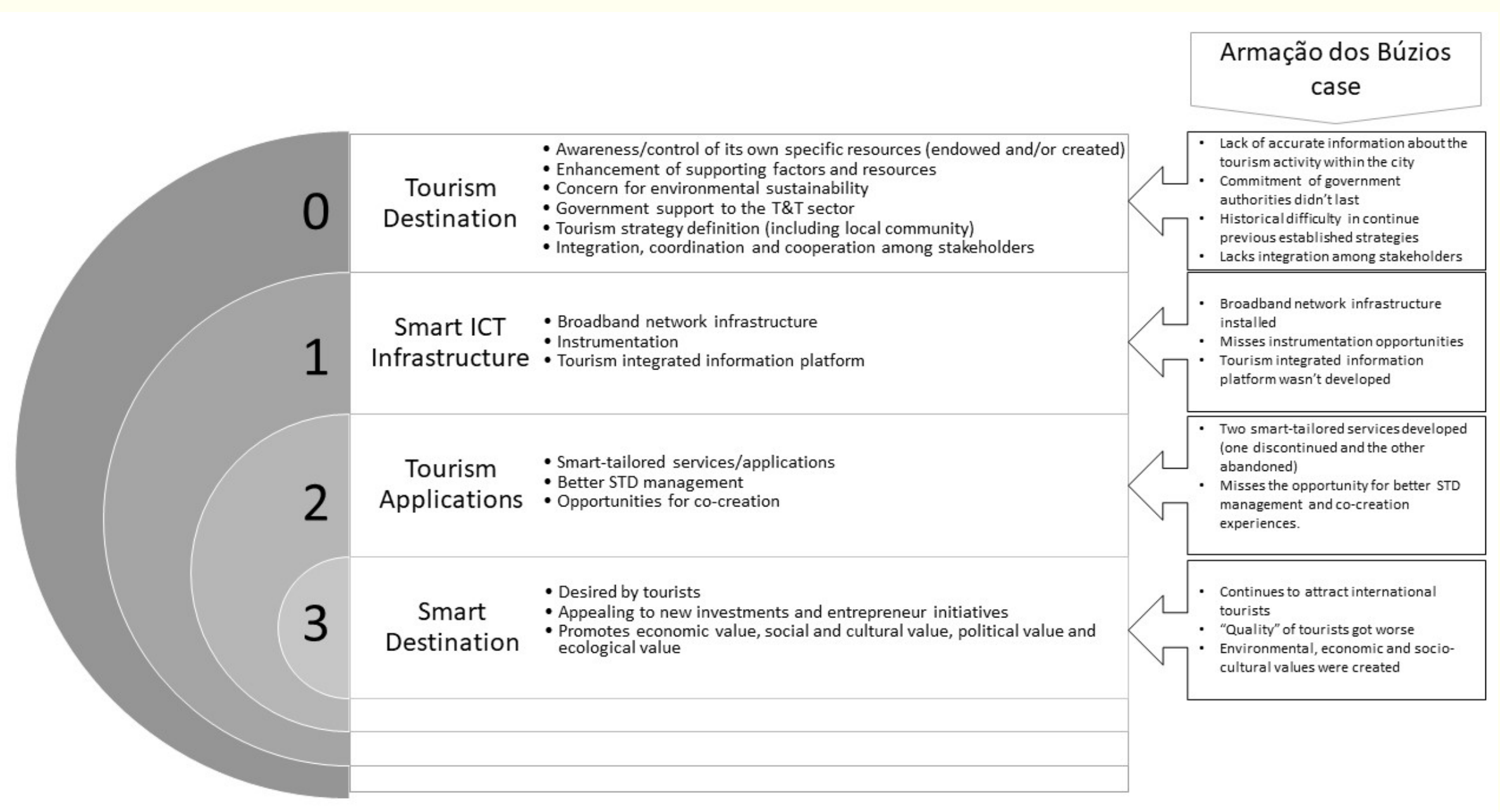

Figure 1. Smart tourism destination development model applied to Búzios case 
Regarding the two tourism applications that emerged during the CIB project, once again they ended up being harmed by Búzios not being able to develop the ground layer of the STDDM. If the context of Búzios, such as the type of streets' pavement, were known in advance and regarded when Ampla acquired the electric bikes, they would probably look for a special bicycle prepared for Búzios' steppingstones. Thus, taking the context of tourism destinations into account before developing tourism applications seems to be crucial for the success of a STD implementation (Avgerou, 2019; Davison \& Martinsons, 2016; Joia \& Kuhl, 2019).

On the other hand, the tourism mobile app developed was neglected due to the lack of engagement of the local population in the project, which once again reinforces the importance of citizens' participation in STD-oriented smart city initiatives (Joia \& Kuhl, 2019).

At last, even not being able to enhance the tourism destination competitiveness, the CIB project has developed some opportunities for public value creation in Búzios. Indeed, the Quilombola project is a good example of how tourism can bring cultural pride, a sense of ownership and control, and reduced vulnerability through diversification, thus leading to entrepreneurial capacity building. In this way, it is possible to perceive what Eisenhardt (1989, p. 539) calls "controlled opportunism," that is, unexpected ancillary effects not previously foreseen in the project, but perceived by the researchers when analyzing the case and its results in loco.

\section{CONCLUSIONS}

To provide a better conceptualization of the STD phenomenon, this research has sought to apply the smart tourism destination development model (Cavalheiro et al., 2020), by examining the transformation process of an international tourism destination into a smart city. The analysis of the case study corroborated that a touristic destination will not be able to be considered smart unless it complies with all STDDM layers. This fact was especially evident for the ground layer as its inadequate development harmed the following layers in the case analyzed.

\section{Contributions of the study}

As a first theoretical contribution, this study brings the concept of smart tourism destination and the use of the STDDM to evaluate enterprises of smart tourism destinations.

As a second theoretical contribution, this work links smart city initiatives with STD ventures, making it clear that one cannot assume that the former will certainly lead to the success of the latter, that is, the transformation of tourism destinations into smart ones cannot be ensured only through smart city projects. In fact, there are several critical issues that must be solved successfully, as established by the STDDM.

That conclusion is even more crucial for developing countries, where social, technological, economic, political, and environmental sustainability cannot be taken for granted. Thus, it is 
dangerous to transplant successful STD projects from developed countries to emerging economies without any type of customization (Avgerou, 2019).

Furthermore, recent research has emphasized the importance of collaborative arrangements involving public sector organizations and private companies for the development of new or improved ICT-enabled tourism services toward the smart transformation of destinations. However, knowledge on public-private partnerships specifically set up for realizing smart innovations, as well as their governance, is still scarce (Errichiello \& Marasco, 2017; Vijayanand, 2013). Thus, as this article addresses the CIB project - a public-private partnership jeopardized mainly by political discontinuity in the city -, this can be considered another theoretical contribution of this research.

With regard to its contributions to public policy and practice, this research clearly exposes the critical role played by local government authorities in implementing STD initiatives. For Ye, Ye, and Law (2020), this is a research gap not yet fully addressed by STD scholars, being also a contribution of this article.

One also realized that political disputes and hidden political agendas can compromise the success of STD initiatives, especially in emerging markets like Brazil, as also supported by Joia and Kuhl (2019). In addition, one perceives the importance of strategies (or lack of them) adopted by local governments to promote the development of smart tourism in their cities, as also perceived in a similar initiative in Dubai (Khan et al., 2017) - in fact, in the case under analysis these strategies remained totally unknown. This issue led Ampla - an energy company - to focus its efforts on the improvement of the energy area of the city, putting aside problems related to water distribution, garbage collection, sewage, mobility, to name just a few.

The important role of context for a successful STD initiative is also a contribution for practice revealed in this study. One realized that for successful STD initiatives, context is 'king' (Davison \& Martinsons, 2016). Thus, awareness about the relevant apps to be developed, local population's demands, technological infrastructures available, cultural aspects of the community, to name just a few, are issues that should be taken into consideration (Avgerou, 2019).

Another contribution of this study for public policy is to show that without the engagement and participation of the local population in a STD endeavor, it is quite difficult for it to succeed, as Joia and Kuhl (2019) pointed out when analyzing smart city endeavors in emerging markets environments. Thus, it is important to present to the local population and also to the tourists the benefits of using the tourism apps available to them (Jasrotia \& Gangotia, 2018).

Finally, this study has also generated valuable information for the local development of Búzios. As previously noted, the city economy is highly dependent on the tourism sector, being this the main source of foreign exchange earnings for the local community. Indeed, part of this income trickles down to different groups of the society, having positive impacts on reducing poverty levels, as supported by Cohen (2012).

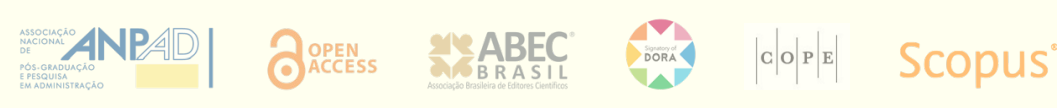


In short, by analyzing the CIB case via the STDDM and by means of evidences triangulation, one has identified several challenges that need to be faced and overcome if the city of Búzios is to become a true STD.

\section{Research limitations}

This study has limitations as any other, as shown below. The first limitation is related to the acuity of perception of the interviewees who took part in this research. According to Scandura and Williams (2000) and Bertucci (2005), these limitations are related to limitations of information available while the respondents are being interviewed, to the epistemological model of the interviewees, and to the possibility of many varied interpretations of the questions they answered in their attempt - not necessarily conscious - to portray a good/bad picture of the smart tourism initiatives under analysis.

In addition to this, as the study uses a single case study approach, some caution is needed when generalizing the results obtained - in other words, the external validity of the study cannot be fully guaranteed (Yin, 2018) and more research is necessary to better validate the results herein presented. In other words, the translation of the results herein presented to other STD initiatives heavily depends on the existence of local contexts similar to that of Búzios - an international tourism destination in a developing country (Mariotto, Zanni, \& Moraes, 2014).

Besides, not all stakeholders could be interviewed. Indeed, the main political authorities refused to give interviews addressing the CIB project, which strengthen the conclusion that the change in the political power was crucial for the misalignment between the smart city initiatives and the tourism needs of the city.

Lastly, notwithstanding the STDDM has been useful to understand why Búzios failed to become an STD, a question remains unanswered, namely: Would Búzios have become a smart tourism destination if the CIB project had been developed as suggested by STDDM? In other words, the work showed that misalignment of STD initiatives with the STDDM does not lead these initiatives to success. However, the other way around was not analyzed. Thus, one expects that this issue might be addressed in further research on smart tourism destinations.

All in all, it is hoped that this work may have revealed the potential of STD initiatives for a country like Brazil - a nation with so many well-ranked touristic destinations.

\section{Notes}

1. More information on the city of Armação dos Búzios may be obtained from https://wikitravel.org/en/Arma\%C3\%A7\%C3\%A3o_dos_B\%C3\%BAzios (retrieved on March, 10, 2020).

2. "Búzios Smart City" in English.

3. Local Hotels and Inns Association [Associação de Hotéis de Búzios].

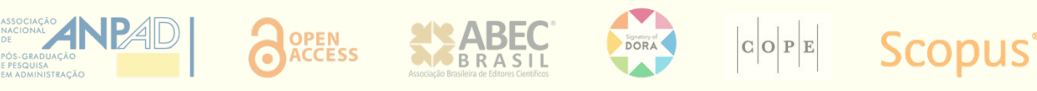


4. Integrated Center for Sustainable Development Studies and Programs [Centro Integrado de Estudos e Programas de Desenvolvimento Sustentável].

5. During the seasons and holidays, the total population of Búzios can be up to ten times greater than the permanent population (see, for instance, http://g1.globo.com/rj/regiao-dos-lagos/eleicoes/2014/noticia/2015/01/armacaodos-buzios-rj-tem-o-maior-verao-de-todos-os-tempos.html) (retrieved on May, 02, 2016).

\section{REFERENCES}

Agência Nacional de Energia Elétrica (2012). Manual do programa de pesquisa e desenvolvimento tecnológico do setor de energia elétrica. Brasilia, DF: Agência Nacional de Energia Elétrica. Retrieved from https://www.aneel.gov.br/documents/656831/14943930/Manual+P\%26D+2012/eaef69f8-5331-43f8-b3effab1c2775ed1

Avgerou, C. (2019). Contextual explanation: Alternative approaches and persistent challenges. MIS Quarterly, 43(3), 977-1006. https://doi.org/10.25300/MISQ/2019/13990

Barbosa, L. G. M. (2012). Índice de competitividade do turismo nacional: 65 destinos indutores do desenvolvimento turístico regional- relatório Brasil 2011. Brasilia- DF: SEBRAE. Retrieved from http://pnc.cultura.gov.br/wpcontent/uploads/sites/16/2017/10/Estudo_de_Competitividade_2011.pdf

Benington, J. (2011). From private choice to public value. In J. Benington \& M. Moore (Eds.), Public value - Theory and practice (pp. 31-51). London: Red Globe Press.

Bertucci, J. L. de O. (2005). Ambiente, estratégia e performance organizacional no setor industrial e de serviços. Revista de Administração de Empresas, 45(3), 10-24. https://doi.org/10.1590/s0034-75902005000300002

Boes, K., Buhalis, D., \& Inversini, A. (2016). Smart tourism destinations: Ecosystems for tourism destination competitiveness. International Journal of Tourism Cities, 2(2), 108-124. https://doi.org/10.1108/IJTC-12-20150032

Buhalis, D., \& Amaranggana, A. (2013). Smart tourism destinations. In Z. Xiang \& I. Tussyadiah (Eds.), Information and communication technologies in tourism 2014 (pp. 553-564). Switzerland: Springer International Publishing.

Cavalheiro, M. B. (2017). Understanding smart tourism destination: Evidence from a smart city project implementation in an international tourism destination (Doctoral dissertation). Fundação Getulio Vargas, EBAPE, Rio de Janeiro, Brazil. Retrieved from http://bibliotecadigital.fgv.br/dspace/handle/10438/19309

Cavalheiro, M. B., Joia, L. A., \& Cavalheiro, G. M. do C. (2020). Towards a smart tourism destination development model: Promoting environmental, economic, socio-cultural and political values. Tourism Planning E⿱ Development, 17(3), 237-259. https://doi.org/10.1080/21568316.2019.1597763

CEPERJ. (2001). Anuário estatístico do estado do Rio de Janeiro. Rio de Janeiro. Retrieved from http://www.ceperj.rj.gov.br/Conteudo.asp?ident $=75$

Coca-Stefaniak, J. A. (2019). Marketing smart tourism destinations - A strategic dilemma. International Journal of Tourism Cities, 5(4), 513-518. https://doi.org/10.1108/IJTC-12-2019-163

Cohen, B. (2012, December). What exactly is a smart city? Fast Company. Retrieved from

https://www.fastcompany.com/1680538/what-exactly-is-a-smart-city

Cornejo-Ortega, J. L., \& Malcolm, C. D. (2020). Touristic stakeholders' perceptions about the smart tourism destination concept in Puerto Vallarta, Jalisco, Mexico. Sustainability, 12(5), 1741. https://doi.org/10.3390/su12051741

Davison, R. M., \& Martinsons, M. G. (2016). Context is king! Considering particularism in research design and reporting. Journal of Information Technology, 31(3), 241-249. https://doi.org/10.1057/jit.2015.19

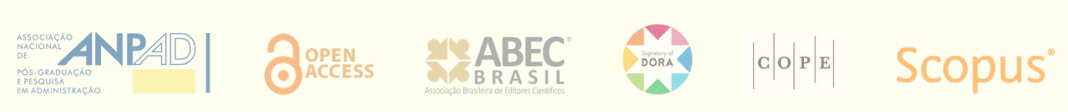


Dursun, A., \& Caber, M. (2016). Using data mining techniques for profiling profitable hotel customers: An application of RFM analysis. Tourism Management Perspectives, 18, 153-160. https://doi.org/10.1016/j.tmp.2016.03.001

Dwyer, L., \& Kim, C. (2003). Destination competitiveness: Determinants and indicators. Current Issues in Tourism, 6(5), 369-414. https://doi.org/10.1080/13683500308667962

Eisenhardt, K. M. (1989). Building theories from case study research. Academy of Management Review, 14(4), 532-550. https://doi.org/10.2307/258557

Errichiello, L., \& Marasco, A. (2017). Tourism innovation-oriented public-private partnerships for smart destination development. Knowledge Transfer to and within Tourism (Bridging Tourism Theory and Practice, Vol. 8, pp. 147-166). Bingley: Emerald Publishing. https://doi.org/10.1108/S2042-144320170000008010

Femenia-Serra, F., \& Ivars-Baidal, J. A. (2021). Do smart tourism destinations really work? The case of Benidorm. Asia Pacific Journal of Tourism Research, 26(4), 365-384. https://doi.org/10.1080/10941665.2018.1561478

Frossard, M. S. (2004). Armação dos Búzios - RJ: De vila de pescadores a destino turístico internacional: Avaliação preliminar dos impactos da atividade turística. Proceedings of Encontro Nacional de Turismo com Base Local, Curitiba, PR, Brazil, 8.

Gephart, R. P. (2004). Qualitative research and the Academy of Management Journal. Academy of Management Journal, 47(4), 454-462. https://doi.org/10.5465/amj.2004.14438580

Global Agenda Council on the Future of Cities. (2015). Top ten urban innovations. Geneva: World Economic Forum. Retrieved from https://www.weforum.org/reports/top-ten-urban-innovations

Gretzel, U., Sigala, M., Xiang, Z., \& Koo, C. (2015). Smart tourism: Foundations and developments. Electronic Markets, 25(3), 179-188. https://doi.org/10.1007/s12525-015-0196-8

Guimarães, A. (2015). Buzios / Brasil: Inesquecivel. Unforgettable . Inolvidable. Belo Horizonte, MG: Author.

Ham, J., Koo, C., \& Chung, N. (2020). Configurational patterns of competitive advantage factors for smart tourism: An equifinality perspective. Current Issues in Tourism, 23(9), 1066-1072. https://doi.org/10.1080/13683500.2019.1566303

Hristov, D., \& Petrova, P. (2018). Destination management plans - a new approach to managing destinations in England: Evidence from Milton Keynes. Current Issues in Tourism, 21(2), 133-153. https://doi.org/10.1080/13683500.2015.1070800

Instituto Brasileiro de Geografia e Estatística. (2016). Panorama: Armação dos Búzios. Retrieved from https://cidades.ibge.gov.br/v4/brasil/rj/armacao-dos-buzios/panorama

Ivars-Baidal, J. A., Celdrán-Bernabeu, M. A., Mazón, J.-N., \& Perles-Ivars, Á. F. (2019). Smart destinations and the evolution of ICTs: A new scenario for destination management? Current Issues in Tourism, 22(13), 1581-1600. https://doi.org/10.1080/13683500.2017.1388771

Jasrotia, A., \& Gangotia, A. (2018). Smart cities to smart tourism destinations: A review paper. Journal of Tourism Intelligence and Smartness, 1(1), 47-56. Retrieved from https://dergipark.org.tr/en/pub/jtis/issue/39024/446754

Joia, L. A., \& Kuhl, A. (2019, May). Smart city for development: A conceptual model for developing countries. Proceedings of International Conference on Social Implications of Computers in Developing Countries (pp. 203-214), Dar es Salaam, Tanzania, 15. Retrieved from https://hal.inria.fr/IFIP-AICT-552/hal-02281315

Jovicic, D. Z. (2019). From the traditional understanding of tourism destination to the smart tourism destination. Current Issues in Tourism, 22(3), 276-282. https://doi.org/10.1080/13683500.2017.1313203

Khan, M. S., Woo, M., Nam, K., \& Chathoth, P. K. (2017). Smart city and smart tourism: A case of Dubai. Sustainability, 9(12), 2279. https://doi.org/10.3390/su9122279 
Királ'ová, A. (2019). Sustainable tourism marketing strategy: Competitive advantage of destination. In Information Resources Management Association (Org.), Sustainable tourism: Breakthroughs in research and practice (Chap. 10, pp. 183-206). Hershey, PA: IGI Global. https://doi.org/10.4018/978-1-5225-7504-7.ch010

Koo, C., Shin, S., Gretzel, U., Hunter, W. C., \& Chung, N. (2016). Conceptualization of smart tourism destination competitiveness. Asia Pacific Journal of Information Systems, 26(4), 561-576. https://doi.org/10.14329/apjis.2016.26.4.561

KPMG. (2012). Infrastructure 100: World Cities Edition. London: Haymarket Network. Retrieved from https://assets.kpmg/content/dam/kpmg/pdf/2014/11/infrastructure-100-world-markets-report.pdf

Lukosevicius, A. P., Marchisotti, G. G., \& Soares, C. A. P. (2017). Framework metodológico para estudos de caso em Administração. REA-Revista Eletrônica de Administração, 16(2), 256-276. Retrieved from http://periodicos.unifacef.com.br/index.php/rea/article/view/1327

Madalozzo, R., \& Fernandes, P. C. (2016). Do strategic behaviors link travel agencies in Brazil? Brazilian Administration Review, 13(3), e160018. https://doi.org/10.1590/1807-7692bar2016160018

Mariotto, F. L., Zanni, P. P., \& Moraes, G. H. S. (2014). What is the use of a single-case study in management research?. Revista de Administração de Empresas, 54(4), 358-369. https://doi.org/10.1590/S0034-759020140402

Massukado-Nakatani, M. S., \& Teixeira, R. M. (2009). Resource-based view as a perspective for public tourism management research: Evidence from two Brazilian tourism destinations. Brazilian Administration Review, 6(1), 62-77. https://doi.org/10.1590/S1807-76922009000100006

Michelotto, F. P. (2019). A representação social de smart city: Uma visão brasileira (Master thesis). Fundação Getulio Vargas, EBAPE, Rio de Janeiro, Brazil. Retrieved from http://bibliotecadigital.fgv.br/dspace/handle/10438/28589

Ministério do Turismo (2012). Estudo da demanda turística internacional: 2005-2011. Brasília: Author. Retrieved from http://www.dadosefatos.turismo.gov.br/2016-02-04-11-54-03/demanda-tur\%C3\%ADstica-internacional.html

Ministério do Turismo (2015). Índice de competitividade do turismo nacional: Relatório Brasil 2015. Brasília: Author. Retrieved from http://www.dadosefatos.turismo.gov.br/indice-de-competitividade-do-turismo-nacional.html

Ministério do Turismo (2017). Estudo da demanda turística internacional: 2012-2016. Brasília: Author. Retrieved from http://www.dadosefatos.turismo.gov.br/2016-02-04-11-54-03/demanda-tur\%C3\%ADstica-internacional.html

Muñoz, A. L. A., \& Sánchez, S. G. (2013). Destinos turísticos inteligentes. Harvard Deusto Business Review, (224), 5866. Retrieved from https://www.harvard-deusto.com/destinos-turisticos-inteligentes

Oye, N. D., Okafor, C. I., \& Kinjir, S. (2013). Sustaining tourism destination competitiveness using ICT in developing countries. International Journal of Computer and Information Technology, 2(01), 48-56. Retrieved from https://citeseerx.ist.psu.edu/viewdoc/download?doi=10.1.1.403.9850\&rep=rep1\&type=pdf

Racherla, P., Hu, C., \& Hyun, M. Y. (2008). Exploring the role of innovative technologies in building a knowledgebased destination. Current Issues in Tourism, 11(5), 407-428. https://doi.org/10.1080/13683500802316022

Ramaprasad, A., Sánchez-Ortiz, A., \& Syn, T. (2017, September). A unified definition of a smart city. International Conference on Electronic Government (pp. 13-24), St. Petersburg, Russia, 16. https://dx.doi.org/10.1007/978-3-319. 64677-0_2

Sales, E. J. C. G., \& Alves, F. D. (2010). O lugar do turismo em Armação dos Búzios - RJ: Ordenamento territorial e questões socioespaciais. Anais do Seminário de Pesquisa em Turismo do Mercosul. Caxias do Sul, RS, Brazil, 6.

Scandura, T., \& Williams, E. (2000). Research methodology in management: Current practices, trends, and implications for future research. The Academy of Management Journal, 43(6), 1248-1264. https://doi.org/10.5465/1556348

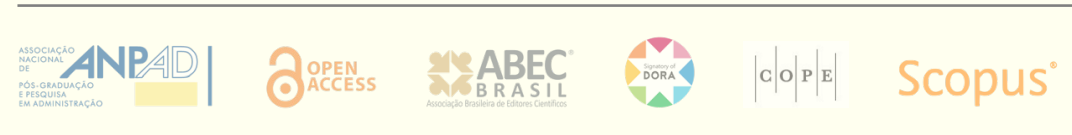


Schaffers, H., Komninos, N., Pallot, M., Trousse, B., Nilsson, M., \& Oliveira, A. (2011, May). Smart cities and the future internet: Towards cooperation frameworks for open innovation. Proceedings of Future Internet Assembly 2011: Achievements and technological promises (pp. 431-446). Budapest, Hungary. https://doi.org/10.1007/978-3642-20898-0_31

SEGITTUR (2015). Informe destinos turísticos inteligentes: Construyendo el futuro. Madrid: Sociedad Mercantil Estatal para la Gestión de la Innovación y las Tecnologías Turísticas, S.A. (SEGITTUR). Retrieved from https://www.thinktur.org/media/Libro-Blanco-Destinos-Tursticos-Inteligentes-construyendo-el-futuro.pdf

Shaffie, S., Ghatari, A. R., Hasanzadeh, A., \& Jahanyan, S. (2019). Developing a model for sustainable smart tourism destinations: A systematic review. Tourism Management Perspectives, 31, 287-300. https://doi.org/10.1016/j.tmp.2019.06.002

Stake, R. E. (1998). Case studies. In N. K. Denzin \& Y. S. Lincoln (Eds.), Strategies of qualitative inquiry (pp. 445454). California: Sage Publications.

Stephenson, M. L., \& Dobson, G. (2020). Deciphering the development of smart and sustainable tourism cities in southeast Asia. Austrian Journal of South-East Asian Studies, 13(1), 143-153. https://doi.org/10.14764/10.ASEAS0033

United Nations (2015). World urbanization prospects: The 2014 revision. New York: United Nations. Retrieved from https://population.un.org/wup/publications/files/wup2014-report.pdf

Vijayanand, S. (2013). Stakeholders and public private partnerships role in tourism management. International Journal of Scientific Eु Engineering Research, 4(2), 1-11. Retrieved from https://www.ijser.org/researchpaper/Stakeholdersand-public-private-partnerships-role-in-tourism-management.pdf

Vilaca, N., Figueiredo, V., Oliveira, L., Ferreira, V., Fortes, M., Correia, W., \& Pacheco, O. (2014). Smart city - caso da implantação em Búzios - RJ. Revista SODEBRAS, 9(98), 16-22. Retrieved from http://sodebras.com.br/edicoes/N98.pdf

Werthner, H., Koo, C., Gretzel, U., \& Lamsfus, C. (2015). Special issue on smart tourism systems: Convergence of information technologies, business models, and experiences. Computers in Human Behavior, 50, 556-557. https://doi.org/10.1016/j.chb.2015.03.042

World Tourism Organization. (2015). Tourism driving trade, fostering development and connecting people. Madrid: World Tourism Organization. https://doi.org/10.18111/9789284417247

World Travel \& Tourism Council (2018). Travel \& tourism: Global economic impact \& issues 2018. World Travel EB Tourism Council. Retrieved from https://dossierturismo.files.wordpress.com/2018/03/wttc-global-economicimpact-and-issues-2018-eng.pdf

Xiang, Z., Magnini, V. P., \& Fesenmaier, D. R. (2015). Information technology and consumer behavior in travel and tourism: Insights from travel planning using the internet. Journal of Retailing and Consumer Services, 22, $244-249$. https://doi.org/10.1016/j.jretconser.2014.08.005

Ye, B. H., Ye, H., \& Law, R. (2020). Systematic review of smart tourism research. Sustainability, $12(8), 3401$. https://doi.org/10.3390/su12083401

Yin, R. K. (2008). Case study research: Design and methods (4 ed.). Thousand Oaks: Sage Publications.

Yin, R. K. (2018). Case study research and applications: Design and methods (6 revised ed). Newbury Park, CA, SAGE Publications.

Zygiaris, S. (2013). Smart city reference model: Assisting planners to conceptualize the building of smart city innovation ecosystems. Journal of the Knowledge Economy, 4(2), 217-231. https://doi.org/10.1007/s13132-01 


\section{Authors' contributions}

$1^{\text {st }}$ author: conceptualization (equal), formal analysis (equal), investigation (equal), methodology (lead), project administration (lead), writing-review \& editing (lead).

$2^{\text {nd }}$ author: conceptualization (equal), formal analysis (equal), supervision (equal), writing-original draft (equal), writing-review \& editing (equal).

$3^{\text {rd }}$ author: conceptualization (equal), project administration (equal), writing-original draft (equal), writing-review \& editing (equal).

$4^{\text {th }}$ author: conceptualization (equal), project administration (equal), supervision (equal), writing-original draft (equal), writing-review \& editing (equal).

\section{Authors}

\section{Mariana Brandão Cavalheiro}

Universidade Federal Fluminense, Programa de Pós-Graduação em Turismo

Av. Milton Tavares de Souza, n 151, térreo, bloco H - CAPTH, Gragoatá, 24210-346, Niterói, RJ, Brazil

mariana_brandao@id.uff.br

(iD) https://orcid.org/0000-0001-6045-9866

\section{Luiz Antonio Joia}

Fundação Getulio Vargas, Escola Brasileira Administração Pública e de Empresas

Rua Praia de Botafogo, n 190, Botafogo, 22253-900, Rio de Janeiro, RJ, Brazil

luizjoia@fgv.br

(iD) https://orcid.org/0000-0002-5903-5190

\section{Gabriel Marcuzzo do Canto Cavalheiro*}

Universidade Federal Fluminense, Departamento de Empreendedorismo e Gestão

Rua Mario Santos Braga, s/n, Centro, 24020-140, Niterói, RJ, Brazil

gabrielmarcuzzo@id.uff.br

(iD) https://orcid.org/0000-0001-5556-8582

\section{Verônica Feder Mayer}

Universidade Federal Fluminense, Faculdade de Turismo e Hotelaria

Rua Prof. Marcos Valdemar de Freitas Reis, s/n, Bloco H, Gragoatá, 24210-201, Niterói, RJ, Brazil vmayer@gmail.com

(iD) https://orcid.org/0000-0002-7543-5215

* Corresponding author

Peer review is responsible for acknowledging an article's potential contribution to the frontiers of scholarly knowledge on business or public administration. The authors are the ultimate responsible for the consistency of the theoretical references, the accurate report of empirical data, the personal perspectives, and the use of copyrighted material.

This content was evaluated using the double-blind peer review process. The disclosure of the reviewers' information on the first page is made only after concluding the evaluation process, and with the voluntary consent of the respective reviewers.

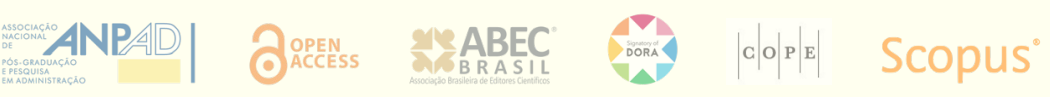

